\title{
The Effect of Nigella sativa Oil to Prevent Decubitus among Bedrest Patients
}

Mardhiah

STIKES Flora Medan, Medan, Indonesia

\begin{abstract}
Using Nigella sativa oil for skin care is a nursing measure to maintain skin integrity to prevent further tissue damage. The oil contains thymoquinone $(27.8 \%-57 \%)$, which has been tested to heal a wound, acting as a potent analgesic and anti-inflammatory. Linoleic acid (57.9\%) and linolenic acid (0.2\%) act as cell-forming substances and helping to moisturize the skin. This study aims to discover the effect of Nigella sativa oil, which is applied to prolonged bedridden patients with the risk of decubitus. This study used a quasiexperimental design with one group pretest-posttest design. Random sampling was used to acquire 34 people as samples by using the probability sampling technique. This study also used paired sample test as a research analysis. The result showed a significant effect using Nigella sativa oil for skin care with a p-value $=0.000(\mathrm{p}<0.05)$.
\end{abstract}

Keywords: skin care; nigella sativa oil; decubitus; bed rest

Received $18^{\text {th }}$ May $2021 \mid$ Revised $3^{\text {th }}$ July $2021 \mid$ Accepted $14^{\text {th }}$ July 2021

*Corresponding author at: JI Rajawali No 24 Medan, STIKes Flora, Medan, Indonesia

E-mail address: mardhiah356@gmail.com 


\section{Introduction}

Decubitus is an skin problem faced by patients with chronic diseases, frail patients, and prolonged paralyzed patients. Even now, it is a secondary pain suffered by many hospitalized patients (Morison, 2013). National Pressure Ulcer Advisory Panel (NPUAP) (2013) showed that the prevalence of decubitus incidence number is increasing every year. The estimates show that 1-3 million people suffer from pressure ulcer in the United States of America.

Several factors forming pressure ulcer can be seen in prolonged bedridden patients. Those factors appear to cause pressure ulcer because the patients have to stay in bed for a long time (several days, months, even years) (Syapitri, 2017).

Regarding nurses' role in preventing pressure ulcers, Potter and Perry (2005) stated three main areas of nursing intervention to prevent pressure ulcers. First, conducting skin care covering hygiene treatment and administering topical medication. Second, mechanical prevention and provision of smooth-surfaced bed, therapeutic mattress, and body repositioning. Third, education (Syapitri, 2017).

Skincare is a nursing measure to maintain skin integrity to prevent further tissue damage. Its goals are to prevent pressure ulcer and skin complications, to treat pressure ulcers due to prolonged pressure to the skin, and act as a treatment (Utomo, et al., 2012).

In recent years, the development of medicine has taken an interest to develop medicine from herbal plants. One of which is Nigella sativa, also known as black cumin. Nigella sativa oil is one of the traditional therapy medicines in wound healing. Various studies have shown the positive effects of Nigella sativa. It has antioxidant, antipyretic, antibacterial, anti-ulcer, antidiabetic properties and potentially boosting the immune system. It consists of protein, low sugar carbohydrates, fatty acids, saponins, and other beneficial substances. Also, thymoquinone and thymol in black cumin have contributed to its microbial and antibacterial effects (Syapitri, 2017).

By applying Nigella sativa oil on the skin, it will maintain skin integrity to prevent further tissue damage because it contains the most active substance, thymoquinone (27.8\%-57\%). It acts as the primary substance tested in wound healing as a potent analgesic and has anti-inflammatory properties. The oil also contains linoleic acid (57.9\%) and linolenic acid (0.2\%), which help to form cells and moisturize the skin due to its vitamin $\mathrm{E}$ and minerals (such as zinc and calcium) maintaining healthy skin. Saponins also play an important role in the wound healing process, accelerate the formation of new blood vessels, and have anti-inflammatory (Syapitri, 2017). 


\section{Research Method}

This research used a Quasi-experiment design with a one-group pretest-posttest design. It was carried out to a randomly selected group observed two times before and after the treatment. The intervention was the application of Nigella sativa oil as skin care to the treatment group.

Table 1. Research Design

\section{One-group pretest-posttest design}

$\mathrm{R} \rightarrow \mathrm{O}_{1} \rightarrow \mathrm{X} \quad \rightarrow \mathrm{O}_{2}$

\section{Note:}

$\mathrm{R}$ : Research respondents

$0_{1}$ : Observation before intervention

$\mathrm{X}$ : Skin Care Intervention using Nigella sativa oil

$\mathrm{O}_{2}$ : Observation after being given intervention

This research was conducted at Dr. Pirngadi Regional Public Hospital, Medan for two weeks, starting from July $1^{\text {st }}$ to July $20^{\text {th }}, 2019$. This research population is patients in the last six months in 2018 totaled 1,549 patients. They are the patients who stayed in the inpatient room having prolonged bedridden at RSUD Dr. Pirngadi, Medan.

This research sample is patients having prolonged bedridden in the inpatient room at RSUD Dr. Pirngadi, Medan. This research used the power analysis table from Pollit \& Beck (2012) to determine which patients to be the sample. The table contains the significance level $(\alpha)$ : 0.05 , effect size, which is the error measure of the null hypothesis $(\gamma): 0.70$, and power, which is the test's power or the power to reject the null hypothesis (1- $\beta$ ): 0.60 ; resulting in 34 people as samples. This research also used the probability sampling technique by simple random sampling. Simple random sampling is the simplest type of probability. Each element is randomly selected to achieve this sampling (Nursalam, 2016).

This study used two data sources. First, primary data. It was obtained directly from the respondents by conducting interviews, observation, and handing out questionnaires. Second, secondary data. It was obtained from various information related to the studied topic. Hospital medical record searching at RSUD Dr. Pirngadi Medan was carried out to obtain facts from the required information.

The research instrument was a demographic data questionnaire containing data such as respondent's names, gender, age, ethnicity, nationality, education, nutritional status, and blood sugar levels. This demographic data was useful to help the researchers finding out the respondent's background, which could influence the research. 
The application of Nigella sativa oil as skin care was measured by Standard Operational Procedure (SOP). This research aims to find out the effect of using Nigella sativa oil as skin care on pressure ulcers and preventing it. This research also used the Braden Scale as the observation sheet. The researcher observed every oil application on the respondents and recorded the changing result after the application into the data collection sheet.

Data analysis used univariate and bivariate analysis. This analysis aims to describe each of the variables studied. The independent variable analysis was carried out on skin care, namely by applying Nigella Sativa Oil. Observations were made once a day for seven consecutive days. The data presentation used tables and interpreted them based on the results obtained. All variables were analyzed descriptively by calculating their frequency.

This study used Paired Sample-Test as the Bivariate analysis to compare the application of Nigella sativa oil as skin care with regular skin care on prolonged bedridden patients. The test will compare the p-value in the sig column (two-tailed) with the probability of ( $\alpha=$ $0,05)$. If $p$-value $<0.05$ then $\mathrm{H} 0$ is rejected. In conclusion, the application of Nigella sativa oil as skin care affects the pressure ulcers of prolonged bedridden patients.

As an ethical consideration, the researcher believes that respondents must be protected by taking into account the following aspects (Polit \& Hungler, 2005):

\section{a. Self Determination}

Respondents were given the freedom to determine whether they were willing to participate in research activities voluntarily. Researchers gave freedom to prospective respondents to participate. Before the prospective respondent stated their willingness, the researcher explained the objectives, benefits, and research procedures. The researcher also explained and confirmed that during this research process, the respondents would not be charged. The researcher bore all data cost needed in this study.

\section{b. Informed Consent Form}

All 34 patients who met the inclusion criteria and had been provided with the explanation of the study's objectives, benefits, and procedures signed a consent form to participate as respondents.

\section{c. Anonymity}

During the research, the respondent's names were not used. Instead, the researcherused respondent's number and their initials to maintain their confidentiality and prevent mistakes when the researcher entered the data. 


\section{d. Confidentiality}

The researcher guaranteed the confidentiality of respondent information, and only certain groups of data will be reported as research results. Respondent's privacy is strictly maintained by keeping the information obtained during the study confidential. The information obtained was only for research purposes. The researcher also guaranteed the respondents that the information obtained in this study is confidential by creating a particular respondent data file that only the researcher knew. If the data has been analyzed and is no longer needed, it will be destroyed.

\section{e. Protection From Discomfort}

The respondents were free from discomfort. The researcher stated that if the respondents were uncomfortable during the research process, they could stop their participation or continue with the intervention of the medical team. If the respondents were experiencing an uncomfortable situation during the research process, the nurse would provide assistance to overcome their discomfort.

\section{Research Results}

\section{a. Univariate Analysis}

Research on the effect of Nigella sativa oil as skin care on prolonged bedridden patients suffering from pressure ulcers had been conducted for 20 days, starting from July 1st, 2019, to July 20th, 2019. This research used the probability sampling technique by using simple random sampling to acquire 34 respondents. Simple random sampling is the simplest type of probability. Each element was randomly selected to achieve this sampling (Nursalam, 2016).

\section{Respondents' Characteristics}

Respondent's identity includes age, gender, ethnicity, and education as follows:

Table 2. Frequency Distribution of Respondent Demographic Data

\begin{tabular}{lcc}
\hline \multicolumn{1}{c}{ Demographic Data } & $\begin{array}{c}\text { Frequency } \\
(\mathbf{f})\end{array}$ & $\begin{array}{c}\text { Percentage } \\
(\mathbf{\%})\end{array}$ \\
\hline Age & 23 & 67.6 \\
50-65 years old & 23 & 26.5 \\
65-75 years old & 9 & 5.9 \\
75 years old & 2 & \\
\hline Gender & & 70.6 \\
Male & 24 & 29.4 \\
Female & 10 & \\
\hline Ethnicity & & \\
Batak & 14 & 41.2 \\
Malay & 7 & 20.6 \\
Minang & 6 & 17.6 \\
Java & 7 & 20.0 \\
& & \\
\hline
\end{tabular}




\begin{tabular}{lcc}
\hline \multicolumn{1}{c}{ Demographic Data } & $\begin{array}{c}\text { Frequency } \\
(\mathbf{f})\end{array}$ & $\begin{array}{c}\text { Percentage } \\
(\mathbf{\%})\end{array}$ \\
\hline Education & & \\
Primary School & 4 & 11.8 \\
Middle school & 10 & 29.4 \\
High school & 17 & 50.0 \\
S1 & 3 & 8.8 \\
S2 & 0 & 0 \\
\hline Total & $\mathbf{3 4}$ & $\mathbf{1 0 0 . 0}$ \\
\hline
\end{tabular}

The results showed that most respondents aged 50-65 years old comprise 23 people (67.6\%). Nine people aged 65-75 years old $(26.5 \%)$ and two people aged $>75$ years old (5.9\%). Based on gender, most respondents are male with 24 people $(70.6 \%)$ and female with ten people $(29.4 \%)$. Based on ethnicity, most respondents are Batak with 14 people (41.2\%), seven Malays (20.6\%), six Minang (17.6\%), and seven Javanese (20.6\%). Based on education, there are four primary school educated respondents (11.8\%), ten middle school educated respondents (29.4\%), 17 high school educated respondents (50\%), and three college-educated respondents $(8.8 \%)$.

Table 3. Frequency Distribution of Decubitus Risk of Before-After Skin Care using Nigella sativa Oil

\begin{tabular}{cccc}
\hline & Decubitus Risk & $\begin{array}{c}\text { Frequency } \\
(\mathbf{f})\end{array}$ & $\begin{array}{c}\text { Percentage } \\
(\mathbf{\%})\end{array}$ \\
\cline { 2 - 4 } Pretest & & 18 & 52.90 \\
& Very high & 14 & 41.20 \\
& High & 2 & 5.90 \\
\hline Medium & $\mathbf{3 4}$ & $\mathbf{1 0 0 . 0 0}$ \\
\hline \multirow{3}{*}{ Posttest } & Total & Frequency & $\begin{array}{c}\text { Percentage } \\
(\boldsymbol{\%})\end{array}$ \\
\cline { 2 - 4 } & Decubitus Risk & 8 & 23.50 \\
& & 17 & 50.00 \\
& High & 9 & 26.50 \\
\hline & Medium & $\mathbf{3 4}$ & $\mathbf{1 0 0 . 0 0}$ \\
\hline
\end{tabular}

As shown in the table above, 18 people $(52.90 \%)$ have a very high risk of decubitus before applying Nigella sativa Oil as skin care. Fourteen people (41.20\%) have a high risk of decubitus, and two people (5.90\%) have a moderate risk of decubitus. After the application of Nigella sativa Oil as skin care, there are eight people (23.50\%) have a high risk of pressure ulcers, 17 people $(50.00 \%)$ have a moderate risk of pressure ulcers, and nine people $(26.50 \%)$ have a low risk of pressure ulcers.

\section{b. Bivariate Analysis}

The bivariate analysis used in this study aimed to see the effect of Nigella sativa oil as skin care on prolonged bedridden patients suffering from pressure ulcers at RSUD Dr. Pirngadi Medan. 
Table 4. Data Normality Test

\begin{tabular}{lcll}
\hline \multicolumn{4}{c}{ Normality Tests } \\
\hline & \multicolumn{3}{c}{ Shapiro-Wilk } \\
\hline Pretest & Statistics & $\mathrm{df}$ & Sig. \\
Posttest & .611 & 34 & .000 \\
A & .707 & 34 & .000 \\
\hline
\end{tabular}

A normality test is used to test whether a variable is normal or not. In this case, normal means having normal data distribution. The researcher used the Shapiro-Wilk test to test data provided that if Asymp, Sig $<0.05$, then the data is normally distributed. Based on the table above, the Sig value of pretest-posttest of Nigella sativa oil as skin care $<0.05$ is 0.000 and 0.000 , respectively. It means that the data tested were normally distributed. Due to this fact, paired sample test was used as the statistical test.

Table 5. Paired Sample Test of Decubitus Risk of Before-After Skin Care using Nigella sativa Oil

\begin{tabular}{lcccccc}
\hline & Decubitus Risk & mean & SD & T & df & $\begin{array}{l}\text { Sig (2- } \\
\text { tailed) }\end{array}$ \\
\hline Pretest & 1.53 & .615 & .105 & & \\
Posttest & 3.03 & .717 &, 123 & 34 & $\mathbf{0 . 0 0}$ \\
\hline
\end{tabular}

Based on the Paired Sample Test results above, the risk of pressure ulcers before and after the intervention results in $\mathrm{p}$-value $=0.000(\mathrm{p}<0.005)$. In conclusion, there is a significant effect between skin care using Nigella sativa oil. This is following the accepted hypothesis. If $\mathrm{p}<0.05$, then $\mathrm{Ha}$ is the accepted hypothesis.

\section{DISCUSSION}

\section{a. Respondents' Demographic Characteristics}

According to Revis (2015), age is an intrinsic factor causing pressure ulcers because the elasticity and vascularity have been decreasing in old age, increasing the risk of pressure ulcers. In this study, all respondents were in the middle age group and the elderly. According to Hurlock (1999), middle-aged and elderly respondents have decreased physical function, and some vital organs are no longer able to function normally. Hence, they tend to be associated with various diseases (Merril \& Verbirugge, 1999; Papalia, 2001).

According to Suriadi (2004, in Widodo 2007), gender is not a risk factor for pressure ulcers. Several important hormonal factors may play a role in explaining the differences between men and women, namely that the hormone estrogen protects women before menopause. Avello and Braden (2002, in Widodo, 2007) also disclosed that the risk of pressure ulcers 
would be more significant when the age is above 80 years. The differences occur because this study is not only conducted on elderly patients but also total bedridden patients.

In terms of ethnicity and culture, they are people's life guidelines, and they have more complexity than just determining the fundamental thoughts. The reality is that culture can open a horizon of competence and human performance as phenomenal social beings. Understanding culture in the context of ideationalism not only refers to types of society and ethnicity but also to formal systems (formal organizations discussing the cultural influence of bureaucratism and professionalism). One does not argue that all community groups have cultural unity to understand the cultural formulation. Instead, each community group shows fundamental cultural differences (Geertz, 1966).

According to Perry and Potter (2006), there are three main nursing interventions to prevent pressure ulcers, namely skin care, surface support, and education. Education affects the knowledge of patients, families, and nurses in preventing pressure ulcers. Lack of knowledge about the prevention will increase the risk of developing pressure ulcers.

Meanwhile, according to Azhar (2005), education is a factor influencing one's behavior. It develops one's maturity and behavior. Thus, he can choose and create a decision more quickly. A highly educated person will behave well expectedly, resulting in creating and choosing decisions more precisely. Also, a highly educated person will maintain healthy behavior, preventing himself from having pressure ulcers and the risk factors of pressure ulcers.

\section{b. Skin Care on Prolonged Bedridden Patients Before using Nigella sativa Oil}

The table above showed that before conducting skin care by applying Nigella Sativa oil, 18 respondents (52.90\%) have a very high risk of developing pressure ulcers. Fourteen respondents $(41.20 \%)$ have a high risk of pressure ulcers, and two respondents $(5.90 \%)$ have a moderate risk of pressure ulcers.

Heineman (2010) explains that the prevention principle of pressure ulcers is to prevent the skin from prolonged pressure or repeated shear. Skin care is also needed to make a smooth skin tissue's circulation. Commonly, the preventive skin care measures are carried out by bathing the elderly with fresh water at least twice a day or, if necessary, doing light massage and applying lotion to the risk skin surface. This treatment is needed to stimulate blood circulation so that the oxygen and nutrients supply to the tissues stays smooth. 


\section{c. The Effect of Skin Care using Nigella Sativa Oil on Prolonged Bedridden Patients Suffering from Pressure Ulcers}

Based on the Paired Sample Test results above, the risk of pressure ulcers before and after the intervention results in $\mathrm{p}$-value $=0.000(\mathrm{p}<0.005)$. In conclusion, there is a significant effect between skin care using Nigella sativa oil. This is following the accepted hypothesis. If $\mathrm{p}<0.05$, then $\mathrm{Ha}$ is the accepted hypothesis.

The results are in line with the research conducted by Utomo (2014). In his research, p-value $(0.000)<0.005$. It can be concluded that there is a significant difference in the average scores of pressure ulcers after applying NS oil to the experimental group and controlled group. In conclusion, the application of NS oil prevents pressure ulcers from occurring in prolonged bedridden patients effectively. This research results also aligns with research conducted by Torra i Bou et al. (2005). The research was a comparative study of the effectiveness of preoxygenation fatty acids, known as Mepentol, on topical medication compared with placebo medication, which has an identical appearance and odor to prevent pressure ulcers. In addition, Mepentol contains oleic fatty acids, palmitic, stearic, palmitoleic, linoleic, gamma-linoleic, arachidonic, and eicosenoic acid with the extract of Equisetum arvense and Hypericum.

Leni (2020) states that essential oils benefit the skin against pressure and friction, providing optimal hydration and preventing cell anoxia. The fatty acids in the oil increase the cohesiveness of the stratum corneum and prevent transcutaneous water loss and excessive cell proliferation. This study also showed that topical application of essential fatty acids effectively increased skin hydration and elasticity and helping to prevent pressure ulcers in patients with poor nutritional status.

This study also aligns with Yusuf (2014) research stating that Nigella sativa (black cumin) has active compounds. Niluh Ringga stated that Nigella sativa oil contains active substances such as thymoquinone, dithymoquinone, thymohydroquinone, and thymol. Thymoquinone is the main active substance in volatile oil (essential oil) of Nigella sativa. It functions as an anti-inflammatory by inhibiting the cyclooxygenase and lipoxygenase pathways which function as allergy and inflammation mediators. In a scientific study, the extract of Nigella sativa seed is proven to increase polymorphonuclear (PMN) cell function. Other studies have also proven Nigella sativa in stimulating the cytokines of Macrophage Activating Factor (MAF)-enhancing macrophage functions that have a vital role in the cellular immune system.

Aside from thymoquinone, Nigella sativa also contains saponins which help in the wound healing process. Apart from being anti-inflammatory, saponins can accelerate the formation 
of new blood vessels in the wound healing process (angiogenesis) through VEGF. Also, zinc in black cumin seed is needed in wound healing due to its role in protein formation and collagen synthesis, which does not directly affect fibroblasts. Fibroblasts will synthesize collagen, and the dermis layer formation will be enhanced by regulating granulation tissue and dermis balance. In addition, fibroblasts will change their structure into myofibroblasts, performing contraction on the tissue to help new tissue close the wound.

The contraction function will be more prominent in extensive defect wounds than in minimal defect wounds. The proliferative phase will end when the dermal epithelium and collagen layers have been formed. The contraction process is visible and will be accelerated by macrophages and platelets. A more specific function of collagen is to form a new tissue forerunner (connective tissue matrix). Fibroblast will release the substrate, sign that macrophage, new blood vessels, and fibroblast are one unit entering the wound area.

\section{Conclusion and Future Research}

Based on the Paired Sample Test results above, the risk of pressure ulcers before and after the intervention results in $\mathrm{p}$-value $=0.000(\mathrm{p}<0.005)$. In conclusion, there is a significant effect between skin care using Nigella sativa oil. This is following the accepted hypothesis. If $\mathrm{p}<0.05$, then $\mathrm{Ha}$ is the accepted hypothesis. This study results can be used as additional knowledge in the nursing world, especially for nurses who conduct self-procedure on skin care using Nigella sativa oil.

\section{REFERENCES}

[1] Andriyani, N.A, Kartinah, Wisardoyo. (2019). Aplikasi Nigella sativa Oil Pada Pasien Bedrest Total Untuk Pencegahan Terjadinya Dekubitus Di Ruang Icu Rs Ortopedi Prof Dr R Soeharso Surakarta. Seminar Nasional Keperawatan Universitas Muhammadiyah Surakarta.

[2] Astuti, J. (2018). Analisis Praktek Klinik Ke Efektifan Massage Punggung Menggunakan Nigella sativa Oil Terhadap Pencegahan Resiko Dekubitus Pada Pasien ICH Post Craniotomi Di Ruang Intensive Care Unit (ICU) RSUD Abdul Wahab Sjahranie Samarinda. Program Profesi Ners, Fakultas Ilmu Kesehatan dan Farmasi, Universitas Muhammadiyah Kalimantan Timur.

[3] Astuti, J., Wahyuni, Tri., Riyani, S. (2018). Clinical Practice Analysis of the Effectiveness of Back Massage Using Nigella sativa Oil on Prevention of Decubitus Risk in Post Craniotomy ICH Patients in the Intensive Care Unit (ICU) Room of RSUD. Abdul Wahabsjahranie Samarinda. Final Scientific Work Ners.

[4] Dewi, Nurfita. (2012). Modern Medicine Series: The Power of Black Cumin. Yogyakarta :New Library Press. 
[5] Dharma, (2011). Nursing Research Methodology (Guidelines for Implementing and Applying Research Results): TIM.

[6] Morison, M.J. (2013). Practical Guide Series: Wound Management. Jakarta: EGC.

[7] National Pressure Ulcer Advisory Panel (NPUAP). (2014). Prevention and treatment of pressure ulcer: quick reference guide.

[8] Notoatmodjo, S. (2012). Health Research Methodology. Jakarta: Rineka Cipta.

[9] Nursalam. (2013). Practical Approach: Nursing Research Methodology. Surabaya: Publisher Salemba Medika.

[10] Pollit, D.F and Beck, C.T (2012). Nursing Research. Generating and Assessing Evidence for Nursing Practice. 9th Edition, JB Lippincott Williams \& Wilkins, Philadelphia.

[11] Potter, PA, and Perry, AG (2005). Nursing Fundamental Textbook: Concepts, Processes, and Practices. Vol 2. Edition 4. Translation by Renata Komalasari et al. Jakarta: EGC.

[12] Sugiyono. (2010). Quantitative, Qualitative, and R\&D Research Methods. Bandung: Alphabeta.

[13] Suheri. (2010). Overview of Days of Hospitalization in the Occurrence of Decubitus Wounds in Immobilized Patients at the HAM Hospital Medan, USU Repository.

[14] Syapitri, H., Mariati, LM, Daniel, G. (2017). Methods of Prevention of Decubitus Wounds in Total Bedrest Patients Through Skin Treatment at RSU. Pearl Sari. Idea Nursing Journal. Vol 8, No 2, 15-22.

[15] Utomo, W., Yulia, I. D., T. Abdurrasyid. (2012). Efektifitas Nigella Sativa Oil Untuk Mencegah Terjadinya Ulkus Dekubitus Pada Pasien Tirah Baring Lama. Jurnal Ners Indonesia, Vol 2, No 2.151-157. 